Journal of Cultural Management and Cultural Policy 2020/1 Creative Cities off the Beaten Path

Zeitschrift für Kulturmanagement und Kulturpolitik 2020/1 Creative Cities off the Beaten Path 
The Journal of Cultural Management and Cultural Policy is dedicated to international perspectives that address a wide range of issues in cultural management and cultural policy research and practice. We invite articles that reflect on organizational structures of creative enterprises, economic and managerial issues in the arts, cultural policy in all its dimensions, as well as creative and aesthetic processes in cultural production, distribution and perception. The journal aims to present multifaceted analysis and rich discourse on current issues in cultural management and cultural policy and to promote the development of research designs and methods relating to both new and established practices in these fields. The journal is open to any theoretical and methodological approach, as long as authors adhere to scholarly rigor.

Die Zeitschrift für Kulturmanagement und Kulturpolitik (Journal of Cultural Management and Cultural Policy) vertritt eine internationale Perspektive auf aktuelle Fragestellungen aus Forschung, Lehre und Praxis in den Feldern Kulturmanagement und Kulturpolitik. Das Themenspektrum umfasst nationale und internationale Kulturpolitik auf allen Ebenen (cultural policy, polity und politics); das Kunst- und Kultursystem /-feld sowie deren Institutionen, Praktiken und Angebote; Akteure in Kultur und den Künsten sowie Prozesse der Produktion, Distribution und Rezeption von Kunst und Kultur. Ebenfalls finden methodische (qualitative, quantitative, experimentelle) und theoretisch-analytische Arbeiten ein Podium, wobei eine prinzipielle interdisziplinäre Offenheit angestrebt ist. 


\section{JOURNAL OF CULTURAL MANAGEMENT AND CULTURAL POLICY}

\section{ZEITSCHRIFT FÜR KULTURMANAGEMENT UND KULTURPOLITIK}

\section{Editors-in-Chief}

Constance DeVereaux, Steffen Höhne, Martin Tröndle

Volume 6 I Number 1

2020

[transcript] 


\section{Editors-in-Chief}

Prof. Constance DeVereaux, PhD, University of Connecticut, USA

Prof. Dr. Steffen Höhne, Hochschule für Musik Franz Liszt Weimar/Friedrich-Schiller-Universität Jena, Germany Prof. Dr. Martin Tröndle, Würth Chair of Cultural Production, Zeppelin Universität Friedrichshafen, Germany

\section{Managing Editor}

Dr. Johanna Schindler, Würth Chair of Cultural Production, Zeppelin University, Friedrichshafen, Germany

\section{Journal Review Editor}

Prof. Dr. Volker Kirchberg, Leuphana Universität Lüneburg, Germany

\section{Book Review Editor}

Prof. Dr. Karen van den Berg, Zeppelin Universität Friedrichshafen, Germany

Dr. Leticia Labaronne, ZHAW School of Management and Law, Winterthur, Switzerland

Dr. Simone Wesner University of London, United Kingdom

\section{Editorial Board}

Prof. Dr. Sigrid Bekmeier-Feuerhahn, Leuphana Universität Lüneburg, Germany

Prof. Milena Dragićević Šešić, PhD, University of Arts in Belgrade, Serbia

Dr. Tal Feder, Indiana University, USA

Prof. Dr. Michael Hutter, Prof. em. Wissenschaftszentrum Berlin für Sozialforschung, Germany

Prof. Dr. Arturo Rodríguez Morató, University of Barcelona, Spain

Prof. Dr. Tiago de Oliveira Pinto, Hochschule für Musik FRANZ LISZT Weimar, Germany

Prof. Dr. Martin Piber, Universität Innsbruck, Austria

Dr. Marcin Poprawsk, Adam Mickiewicz University in Poznan, Poland

Prof. Dr. Dan Eugen Ratiu, Babeş-Bolyai University, Romania

Prof. Deborah Stevenson, PhD, Western Sydney University, Australia

Prof. Dr. Tasos Zembylas, Universität für Musik und darstellende Kunst Wien, Austria

Recommended citation: DEVEREAUX, Constance (2020): The Politics of Creativity. A Conversation with Deborah Stevenson and Justin O'Connor. - In: Journal of Cultural Management and Cultural Policy / Zeitschrift für Kulturmanagement und Kulturpolitik, 6/1, 9-20.

The journal is available for annual subscription directly from the publisher. The subscription begins with the current issue and includes all issues of one year. Delivery of the subscribed issues occurs immediately after their appearance. Invoicing occurs with delivery of the first issue of a year. The subscription is automatically continued by one year, unless canceled with the publisher by February 1 st.

The Journal of Cultural Management and Cultural Policy is available in bookstores worldwide. Further information available at: http://www.transcript-verlag.de/zkmm.

\section{Bibliographic information published by the Deutsche Nationalbibliothek}

The Deutsche Nationalbibliothek lists this publication in the Deutsche Nationalbibliografie; detailed bibliographic data are available online at http:/dnb.d-nb.de; indexed in EBSCOhost databases.

\section{(C) 2020 transcript Verlag, Bielefeld}

All rights reserved. No part of this book may be reprinted or reproduced or utilized in any form or by any electronic, mechanical, or other means, now known or hereafter invented, including photocopying and recording, or in any information storage or retrieval system, without permission in writing from the publisher.

Cover Layout: Leaky Studio

Copy editing: Justin Chapman, Constance DeVereaux, Steffen Höhne, Johanna Schindler, Martin Tröndle Typesetting: Marie Czeiler, Annika-Louisa Wismer, Wolf-Georg Zaddach

ISSN: $2701-8466$

eISSN: 2701-9276

ISBN Print: 978-3-8376-4957-4

ISBN PDF: $978-3-8394-4957-8$

Up to Volume 5, issue 2/2019 published as "Zeitschrift für Kulturmanagement: Kunst, Politik, Wirtschaft und Gesellschaft" (ISSN 2363-5562 / eISSN 2363-5533)

Printed on permanent acid-free text paper. 